( 7 )

\title{
運動感覚の生成機構に関する心理物理的指標を 用いた検討
}

\author{
柴田恵理子 ${ }^{1,2}$, 金子文成 ${ }^{1,2}$, 高橋良輔 ${ }^{1,3}$ \\ ${ }^{1}$ 札幌医科大学保健医療学部未来医療ニューロリハビリテーション研究開発部門, \\ ${ }^{2}$ 札幌医科大学保健医療学部理学療法学第一講座, \\ 旭川リハビリテーション病院
}

\begin{abstract}
要旨 体性感覚のうち, 運動に関する感覚を運動感覚という。運動感覚が生成され, 知覚する過 程においては, さまざまな感覚受容器から生じる感覚入力の統合, およびそれらの感覚種を介し て生じる運動感覚と運動を実行しようとする際に発せられる運動指令が統合される。これまで 我々は，筋紡錘からの求心性入力の統合と随意的な運動のイメージが運動感覚に及ぼす影響，お よび, 筋紡錘からの求心性入力と視覚入力の組み合わせが運動感覚に及ぼす影響について, 心理 物理的指標を用いた研究を継続してきた。 本研究により, 拮抗関係にある筋からの感覚入力が統 合され運動を知覚する場合においても，感覚入力と運動イメージによる脳活動が統合されること， および自己運動錯覚を誘導できるような異種感覚入力が統合され, 運動感覚が生成されることが 明らかとなった。
\end{abstract}

キーワード : 運動感覚, 筋紡錘, 運動イメージ, 視覚

\section{1.はじめに}

体性感覚のうち，運動に関する感覚を“運動感 覚”という。運動感覚の生成には, 筋や腱, 関節, そして皮虐などに存在するさまざまな感覚受容器か らの入力信号，および運動指令に伴う中枢神経系の 活動が寄与している ${ }^{1,2)}$ ，例えば，肘関節を屈曲す ると上腕二頭筋が短縮し，上腕三頭筋が伸張される。 それに伴い, 时関節周囲筋の筋紡錘 Ia 群線維や II 群線維に求心性の発射活動が生じる。その一方, 表 在では上腕三頭筋側の皮膚が伸張され，上腕二頭筋 側の皮膚が圧迫されることによって, 皮膚に存在す
る感覚受容器から発射活動が生じる，さらに中枢で は, 肘関節屈曲の運動指令に伴い, 遠心性コピーあ るいは随伴放電とよばれる活動が生じる ${ }^{3)}$.このよ うに, さまざまな感覚受容器から生じる感覚入力ゃ, 運動を実行しようとする際に発せられる運動指令が 同時に生じているような状況下で, 運動感覚は生成 されている.

運動感覚の生成機構に関する探索は, 深部感覚や 視覚といった様々な感覚種の入力によって, 受動的 に運動をしている感覚を知覚させる方法を利用して 行なわれてきた。これを自己運動錯覚という ${ }^{4 \sim 6)}$. 自己運動錯覚が誘導されると, 現実には運動をして いないにも関わらず，あたかも自己の四肢が動いて 
いるような感覚が生じる，本稿では，この自己運動 錯覚を利用して我々が継続してきた運動感覚に関す る研究のうち, 随意的な運動のイメージと感覚入力, および深部感覚と視覚の組み合わせによって誘導さ れる運動感覚に関する研究をまとめ, 紹介する。

\section{2. 随意的な運動のイメージと感覚入力の 統合によって誘導される運動感覚 ${ }^{7}$}

\section{1 背景}

上腕二頭筋腱に対して適切な周波数で振動刺激を 付与すると，実際には関節運動が生じていないにも 関わらず，刺激側の时関節が伸展するような運動感 覚が誘導される ${ }^{8)}$. 筋腱に振動刺激を与えると, 主 に刺激された筋の筋紡錘 Ia 群線維から刺激に応じ た発射活動を記録できることが微小神経電図を用い た研究により明らかになった ${ }^{9 \sim 11)}$. I a 群線維は筋 が伸張される速度への感受性が高い，そのため，Ia 群線維に発射活動が生じることで刺激した筋が伸張 する方向への関節運動を知覚するものと考えられて いる ${ }^{9)}$.

この原理を利用し, Gilhodesらは肘関節において 拮抗関係にある筋に対して, 異なる周波数で同時に 振動刺激を与えると, より高い周波数で刺激された 筋が伸張される方向への運動を知覚することを報告 した ${ }^{12)}$.さらに両筋に対して同じ周波数の振動刺激 を付与した場合には, 運動を知覚しなかった。この ことから, 拮抗関係にある筋に対して振動刺激を与 え, 複数筋の筋紡錘から同時に求心性入力が生じる と, それらが統合されて運動感覚が誘導されるよう な生理学的なメカニズムが存在するということがい える。

一方で Kitada らは, 振動刺激中に運動イメージ を行わせると, 振動刺激単独の場合とは異なる運動 を知覚することを報告した ${ }^{13)}$ 。この背景には, 運動 イメージによる中枢神経系の活動により，筋紡錘か らの求心性入力によって誘導される運動感覚が修飾 されるような生理学的メカニズムが存在しているも のと考える。

以上より, 運動感覚が生成される背景には, 拮抗
関係にある筋の筋紡錘から生じた求心性入力が統合 されるようなメカニズム, さらに, 筋紡錘からの求 心性入力と運動イメージによる脳活動が統合される ようなメカニズムが存在していることが示唆される しかし, 運動感覚が生成される過程において, この ような機構が同時に働くような状況下でどのように 運動を知覚するのかは明らかでない。このような背 景から,ここで紹介する研究では拮抗関係にある複 数筋の筋紡錘からの求心性入力と運動イメージが同 時に生じるような状況において，それらが統合され ることで生じる運動感覚の変化を検証した。

\section{2 方法}

(1) 対象

被験者は健康な右利きの成人 14 名 $(23.6 \pm 4.7$ 歳, $170.7 \pm 6.5 \mathrm{~cm}, 65.7 \pm 6.8 \mathrm{~kg})$ とし, 左手を対象と した。本研究は札幌医科大学倫理委員会の承諾を得 た上で実施した。また、ヘルシンキ宣言に従い, 被 験者のプライバシーと人権の保護に十分留意をして 実験を実施した。測定肢位は，安楽な椅子座位とし た，左手関節は掌背屈中間位とし，自作の台に第 5 中手骨が接地するようリラックスした状態で前腕を 置いた（図 1 )。なお，刺激中は閉眼とした。

(2) 振動刺激

筋紡錘からの求心性入力を生じさせるために，振 動刺激装置（VB115, TECHNO CONCEPT, France）を用いた。刺激端子は長さ $7 \mathrm{~cm}$, 幅 $3.5 \mathrm{~cm}$ のものを使用し, 左手関節掌屈筋と背屈筋 を刺激するよう, 前腕遠位部の掌側と背側に固定し た。手関節背屈筋に振動刺激を与えると掌屈の運動 錯覚, 一方手関節掌屈筋に振動刺激を与えると背屈 しているような運動錯覚を誘導することができる.

振動刺激周波数は 40 $110 \mathrm{~Hz}$ とし, 掌屈筋と背 屈筋のどちらか一方に $40 \mathrm{~Hz}, 70 \mathrm{~Hz}$ で刺激する片 側刺激（背屈筋 vs. 掌屈筋： $40 \mathrm{~Hz}$ vs. $0 \mathrm{~Hz}, 70 \mathrm{~Hz}$ vs. $0 \mathrm{~Hz}, 0 \mathrm{~Hz}$ vs. $40 \mathrm{~Hz}, 0 \mathrm{~Hz}$ vs. $70 \mathrm{~Hz}$ ) と, 両側 を同時に刺激する両側刺激（背屈筋 vs. 掌屈筋 : $95 \mathrm{~Hz}$ vs. $55 \mathrm{~Hz}, 110 \mathrm{~Hz}$ vs. $40 \mathrm{~Hz}, 55 \mathrm{~Hz}$ vs. $95 \mathrm{~Hz}$, $40 \mathrm{~Hz}$ vs. $110 \mathrm{~Hz})$ を設けた。この際, 両側刺激で の周波数の差（背屈筋一掌屈筋）を $40 \mathrm{~Hz}, 70 \mathrm{~Hz}$, 


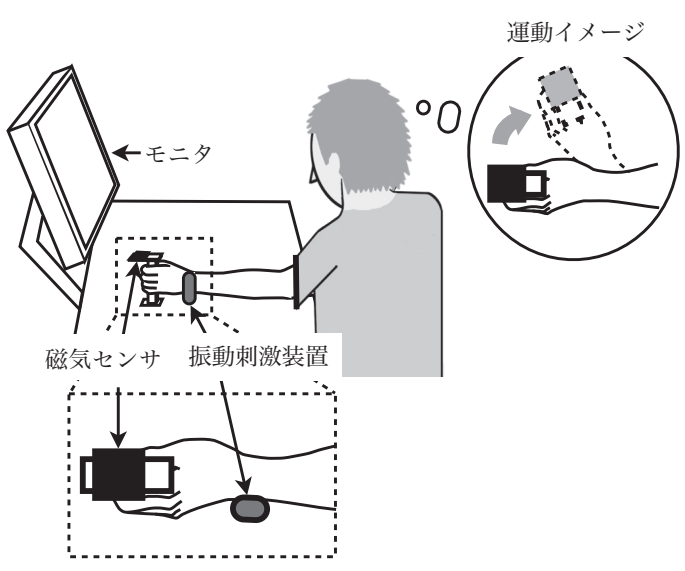

図 1 実験環境

実験環境を示した模式図である。刺激端子は，左手関節掌屈 筋と背屈筋を刺激するよう，前腕遠位部の掌側と背側に固定 した，磁気センサは，手置き台に固定することで，手置き台 の回転角度を記録した。被験者の目の前にモニ夕を設置し, 左手関節の位置をリアルタイムに表示した。

$-40 \mathrm{~Hz}, \quad-70 \mathrm{~Hz}$ にすることによって，「両側刺激 での両筋の周波数の差」と「片側刺激での周波数」 を一致させた。

振動刺激装置はパーソナルコンピューターに接続 し，刺激周波数と刺激開始のタイミングを付属のソ フトウェア (Pivot VB 115, TECHNO CONCEPT, France）で制御した. 周波数に関わらず, パルス 幅は $5 \mathrm{~ms}$ ，振動幅は $0.25 \mathrm{~mm}$ となるよう設定した。 振動刺激時間は 3 秒間とした。

（3）運動イメージ

振動刺激と同時にイメージする運動は, 左手関節 が 3 秒間で中間位から最大掌屈位まで掌屈する運動 とし，一人称的イメージを想起させた。事前に被験 者が運動イメージを行なっていることを自覚できる ようになるまで, 運動イメージの練習を行わせた。 具体的には，まず一定の速度で手関節中間位から最 大掌屈位まで掌屈できるようになるまで, 手関節掌 屈運動を反復して練習させた。 その後, 練習した運 動を実行しているようなイメージを行わせた。この 際, 手関節掌屈筋と背屈筋に電極を貼付して, モ二 タにオンラインで筋電図を表示しながら運動イメー ジの練習を行わせた。これにより，筋収縮なしに運 動イメージを行なっていることを被験者自身に確認 させた。そして運動イメージができていると被験者
が自覚できるようになったことを確認した上で実験 を開始した。

(4) 実験条件

各周波数での振動刺激中に運動イメージを行う条 件（Vib+MI 条件）と行わない条件（Vib 条件）を 設定し，3 試技ずつ実施した。なお，各試技間には 十分な休䟤を挟んだ。振動刺激中に知覚した関節運 動を刺激終了後に同側で再現させ, 磁気センサで再 現中の手関節角度を記録した。記録した角度データ から角速度を算出した。

本研究では，知覚した運動がどのようなものであ つたかを心理物理学的指標で表すために，知覚した 運動の速度を関節運動で再現させた際の角速度を用 いた，過去の研究から，振動刺激の周波数と，振動 刺激によって動員される Ia 群線維の発射頻度は 1 対 1 の関係にあることが分かっている ${ }^{9)}$. そして, 振動刺激の周波数が増加するにつれて, Ia 群線維 の発射頻度が増加し, それに伴い, 知覚した運動を 再現させた際の角速度が増大することも明らかにな っている ${ }^{9)}$. そのため, 多くの研究において, 振動 刺激によって知覚した運動を表現するための指標に は，その運動を再現させた際の角速度が用いられて いる ${ }^{9,10,12,14)}$. 以上の理由より, 本研究においても, 知覚した運動がどのようなものであったかを表す指 標として角速度を用いた。

(5) デー夕解析

解析手順として，まず記録した角度データをロー パスフィルター $(1 \mathrm{~Hz})$ にかけた。知覚した運動は, 加速期, 減速期, さらに等速運動が行われる時間帯 を含めた運動として表現される。そのため，等速運 動の部分のみではなく，明確な運動を知覚した時間 帯の運動を表現するために，その区間を解析区間 （図 2）として切り出した。解析区間は，運動開始 点の 1 秒前から運動終了点の 1 秒後までの区間とし た。運動開始点は, 運動前安静 1 秒間の角度データ を平均し, 平均值 $+3 \mathrm{SD}$ となった時点と規定した。 運動終了点は, 運動後安静 1 秒間の角度デー夕を平 均し, 平均值 $-3 \mathrm{SD}$ となった時点と規定した。解 析区間の角度データから以下の式 1 を用いて S 字 曲線を近似し，最大角速度を算出した。 


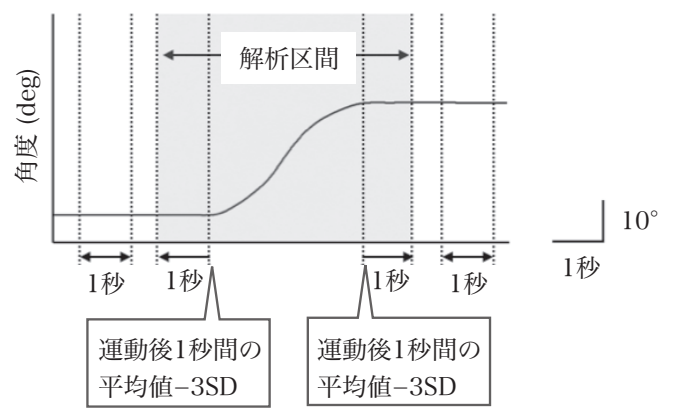

図 2 解析区間

解析区間を示す。解析区間は, 運動前安静 1 秒間の平均值 $+3 \mathrm{SD}$ となった時点を開始位置とし, 運動後安静 1 秒間の平 均值 $-3 \mathrm{SD}$ となった時点の 1 秒後を終了位置とする.

式 $1: y=a /\{1+b \cdot \exp (-c \cdot x)\}$

(6) 統計学的解析

まず Vib 条件と Vib + MI 条件において，振動刺 激周波数 $(40 \mathrm{~Hz}, 70 \mathrm{~Hz},-40 \mathrm{~Hz},-70 \mathrm{~Hz})$ と刺激 部位（片側刺激，両側刺激）を要因とした反復測定 による二元配置分散分析を実施した。次に，片側刺 激の条件において, 振動刺激周波数 $(40 \mathrm{~Hz}, 70 \mathrm{~Hz}$, - $40 \mathrm{~Hz},-70 \mathrm{~Hz})$ と運動イメージ（Vib+MI 条件， Vib 条件）を要因とした二元配置分散分析を行った 同様に, 両側刺激の条件においても周波数 $(40 \mathrm{~Hz}$, $70 \mathrm{~Hz},-40 \mathrm{~Hz},-70 \mathrm{~Hz})$ と運動イメージを要因と した二元配置分散分析を行った，全ての解析に扔い て，有意な交互作用があった場合，多重比較として 単純主効果の検定を行った。有意水準は 5 \%とした.

\section{3 結果}

（1）片側刺激と両側刺激によって知覚する運動の角 速度

片側刺激と両側刺激の各条件において, 振動刺激 のみで知覚した運動を再現させた際の角速度の平均 值を図 3 に示す。片側刺激において, 背屈筋を刺激 した条件では掌屈方向への運動を知覚した。また, 掌屈筋を刺激した条件では，背屈方向への運動を知 覚した，次に両側刺激において，掌屈筋よりも背屈 筋を高周波数で刺激した条件では，掌屈方向への運 動を知覚した，背屈筋よりも掌屈筋を高周波数で刺 激した条件では, 背屈方向への運動を知覚した.

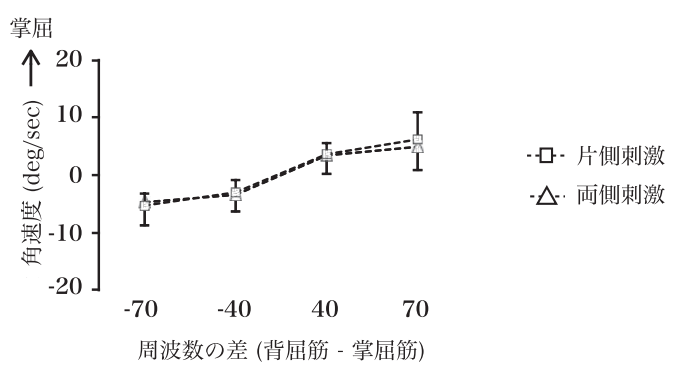

図 3 振動刺激単独によって知覚した運動

片側刺激と両側刺激によって知覚した運動を再現させた際の 角速度を示す。

反復測定による二元配置分散分析の結果, 振動刺 激周波数の要因に有意な主効果があったが, 刺激部 位の要因には有意な主効果がなかった（振動刺激の 周波数: $\mathrm{F}=12.071, \mathrm{p}=0.003$, 刺激部位: $\mathrm{F}=$ $0.319, \mathrm{p}=0.582)$. また, 振動刺激の周波数と刺激 部位の要因には, 有意な交互作用がなかった（F= $1.218, \mathrm{p}=0.294)$. このことから, 片側刺激と両側 刺激ともに振動刺激の周波数が変化すると知覚する 運動の角速度も変化し, 片側刺激で用いた周波数と 両側刺激で用いた両筋への周波数の差が一致した場 合, 同じ速度の運動を知覚することが示された，

（2）片側刺激中に運動イメージを重畳することで知 覚する運動の角速度

各周波数条件において, 知覚した運動を再現させ た際の角速度の平均值を図 $4 \mathrm{~A}$ に示す. 全ての周 波数条件において, 運動イメージを行った条件では, 運動イメージを行わない条件と比較して掌屈運動の 角速度が増大した。

反復測定による二元配置分散分析の結果, 振動刺 激の周波数と運動イメージの要因ともに, 有意な主 効果があった（振動刺激の周波数： $\mathrm{F}=5.167, \mathrm{p}=$ 0.039 , 運動イメージ： $\mathrm{F}=14.956, \mathrm{p}=0.002)$.さ らに, 振動刺激の周波数と運動イメージ要因におい て, 有意な交互作用があった $(\mathrm{F}=4.080, \mathrm{p}=0.030)$. 単純主効果の検定の結果, $40 \mathrm{~Hz},-40 \mathrm{~Hz}$, $-70 \mathrm{~Hz}$ に打いて, Vib 条件と比較して Vib $+\mathrm{MI}$ 条 件の角速度が有意に増大した。また, $\mathrm{Vib}+\mathrm{MI}$ 条 件と Vib 条件ともに, $-70 \mathrm{~Hz}$ と $-40 \mathrm{~Hz}$ よりも $40 \mathrm{~Hz}$ と $70 \mathrm{~Hz}$ でそれぞれ角速度が有意に増大した。 
A

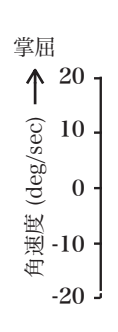

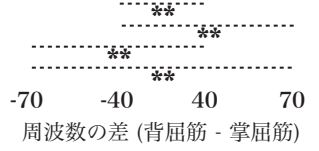

C

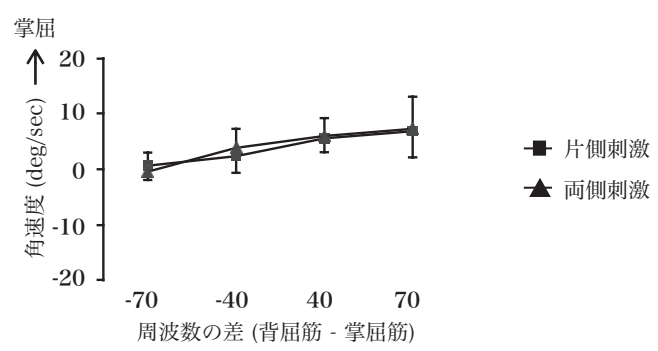

B

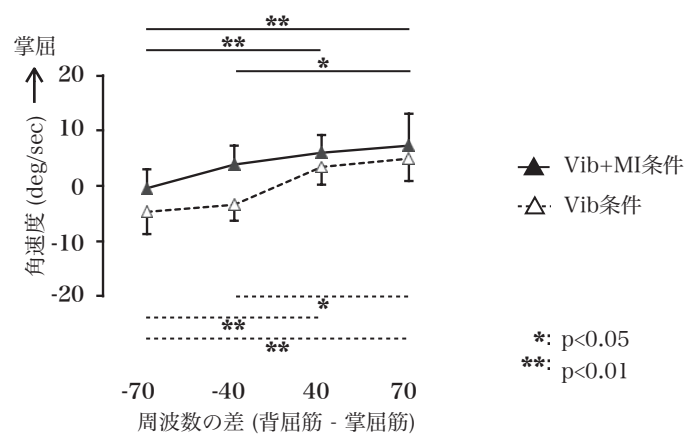

図 4 振動刺激と運動イメージの組み合わせで知覚した運動

片側刺激中に運動イメージを重畳した際に知覚した運動を再現させた際の角速度（A)，両側刺激中に運動イメージを重畳した際に 知覚した運動を再現させた際の角速度 (B), 運動イメージ中の片側刺激と両側刺激の比較 (C) を示す。有意差を示す線は, 実線 が Vib+MI 条件, 点線が Vib 条件の結果を示す.

このことから，振動刺激の周波数が変化する，ある いは運動イメージを行うことによって, 知覚する運 動の角速度が変化することが示された。

(3) 両側刺激中に運動イメージを重畳することで知 覚する運動の角速度

各周波数条件において, 知覚した運動の角速度の 平均值を図 $4 \mathrm{~B}$ に示す。全ての周波数条件において, 運動イメージを行った条件では, 運動イメージを行 わない条件と比較して, 掌屈方向への運動の角速度 が増大した。

反復測定による二元配置分散分析の結果, 振動刺 激の周波数と運動イメージの要因ともに，有意な主 効果があった（振動刺激の周波数 : $\mathrm{F}=16.966, \mathrm{p}$ $<0.001$, 運動イメージ : F = 7.567, $\mathrm{p}=0.017)$. さ らに, 振動刺激の周波数と運動イメージ要因におい て，有意な交互作用があった $(\mathrm{F}=5.254, \mathrm{p}=0.016)$. 単純主効果の検定の結果, Vib 条件, Vib $+\mathrm{MI}$ 条件 ともに $-70 \mathrm{~Hz}$ よりも $40 \mathrm{~Hz}$ と $70 \mathrm{~Hz}, \quad-40 \mathrm{~Hz}$
よりも $70 \mathrm{~Hz}$ でそれぞれ角速度が有意に増大した。 このことから, 両筋への振動刺激周波数の差が変化 する, あるいは運動イメージを行うことによって, 知覚する運動の角速度が変化することが示された.

（4）運動イメージ中に知覚する運動の角速度におけ る片側刺激と両側刺激の比較

片側刺激と両側刺激の条件における運動イメージ 中の角速度の平均值を図 $4 \mathrm{C}$ に示す. 反復測定によ る二元配置分散分析の結果, 振動刺激の周波数の要 因に有意な主効果があったが, 刺激部位の要因には なかった（振動刺激の周波数： $\mathrm{F}=5.672, \mathrm{p}=0.029$, 刺激部位： $\mathrm{F}=1.253, \mathrm{p}=0.283)$. さらに, 振動刺 激の周波数と刺激部位の要因には有意な交互作用が なかった $(\mathrm{F}=1.026, \mathrm{p}=0.336)$.このことから， 運動イメージを重畳した場合には, 片側刺激と両側 刺激ともに振動刺激の周波数が変化すると知覚する 運動の角速度が変化し, 片側刺激で用いた周波数と 両側刺激で用いた両筋への周波数の差が一致した場 
82 バイオメカニズム 23

合，同じ速度の運動を知覚することが示された。

\section{4 考察}

本研究では, 両側刺激で用いた動筋・拮抗筋に対 する周波数の差と片側刺激で用いた周波数を一致さ せた場合，知覚する運動の角速度も一致した。この 結果は Gilhodesらが述べているように，拮抗関係 にある筋を同時に振動刺激した場合, 知覚する運動 の速度は両側の筋紡錘からの感覚信号の差に依存す るという報告 ${ }^{12)}$ と矛盾せず，過去の研究結果を支持 するものである ${ }^{14)}$.

片側刺激中に運動イメージを重畳した場合, 背屈 筋への振動刺激によって掌屈の運動錯覚が生じる条 件では, 運動イメージを行った際に知覚する掌屈方 向への運動の角速度が増大した。このことから, 運 動イメージと同じ方向への運動を知覚するような振 動刺激を与えた場合，運動イメージを重畳すること によって知覚する運動の角速度がイメージした方向 へ増大することが示された。 また，掌屈筋への振動 刺激によって背屈の運動錯覚が生じる条件では, 運 動イメージを行った際には知覚する運動の方向が掌 屈方向へ変化した，このことから，運動イメージと 異なる方向への運動を知覚するような振動刺激を与 えた場合，運動イメージを重助することによって知 覚する運動の角速度が減少した, つまり, 知覚する 運動がイメージした方向へ偏移するような現象が生 じることが示された。

同様に, 両側刺激中に運動イメージを重冨した場 合, 掌屈筋よりも背屈筋へ高周波数の振動刺激を与 えた条件では, 運動イメージを重畳した際に知覚す る掌屈方向への運動の角速度が増大した。このこと から, 動筋・拮抗筋に対する異なる周波数の振動刺 激によって, 運動イメージと同じ方向への運動を知 覚する場合には, 運動イメージを重畳することによ って知覚する運動の角速度がイメージした方向へ増 大することが示された，また，背屈筋よりも掌屈筋 へ高周波数の振動刺激を与えた条件では, 運動イメ ージを重畳した際に知覚する運動の方向が掌屈方向 へ変化した，このことから，動筋・拮抗筋に対する 異なる周波数の振動刺激によって運動イメージと異
なる方向への運動を知覚する場合には, 運動イメー ジを重畳することによって知覚する運動の角速度が 減少した, つまり, 知覚する運動がイメージした方 向へ偏移するような現象が生じることが示された. 以上より，拮抗関係にある筋紡錘から同時に異なる 求心性入力が生じ, 運動錯覚が誘導される状況下に 拈いても, 運動イメージを行うことによって, 知覚 した運動がイメージした方向へと変化することが明 らかとなった。

さらに本研究では, 両側刺激で用いた両筋への周 波数の差と, 同じ周波数を用いて片側刺激を行った その結果, 周波数の差が等しい条件間では, 運動イ メージを重畳した際に同じ速度の運動を知覚するこ とが示された。このことから，拮抗関係にある筋へ の振動刺激中に運動イメージを行うことによって誘 導される運動感覚は, 動筋・拮抗筋からの求心性入 力の合計量に関わらず，その差に依存して変化する ことが新たに示された。

\section{3．異種感覚入力の統合で誘導される運動 感覚}

\section{1 背景}

筋腱に振動刺激を与えると, 筋紡錘 Ia 群線維に は振動刺激に対して 1 対 1 の関係で発射活動が生じ， あたかも刺激された筋が伸張した方向へ関節運動が 生じたような運動錯覚が誘導されることは既に述べ た。四肢の自己運動錯覚は, 振動刺激 ${ }^{8,9,15)}$ の他に 皮膚への伸張刺激 ${ }^{16,17)}$ や視覚刺激 ${ }^{4,5,18)}$ などによっ ても誘導できる，そこで，次に自己運動錯覚を誘導 できるような異種感覚入力が同時に生じるような状 況下では，どのような運動を知覚するのか検証した。

振動刺激と皮膚伸張刺激を同時に付与した場合に 誘導される運動感覚については既に多数の報告され ており, 振動刺激によって誘導される運動錯覚の強 度には, 皮膚からの入力の有無が影響することがわ かっている ${ }^{16,17,19,20)}$. Collins らは振動刺激を用い て手指屈曲運動の錯覚を誘導し，同時に手背部の皮 膚を伸張するような刺激を付与した。 その結果, 振 動刺激を単独で実施した場合よりも，知覚した手指 
屈曲角度が増大した ${ }^{16)}$ ，それぞれの感覚刺激を単独 で付与した場合には, どちらの刺激でも手指が屈曲 するような関節運動を知覚する。そして, 知覚した 運動の角速度は運動感覚の強さを示していることか ら, 筋腱と皮膚に存在する感覚受容器からの求心性 入力が, どちらも同じ方向への運動を知覚するよう な入力であった場合, それらが同時に生じることで, より強い運動感覚が誘導されたと言い換えることが できる。

一方, 我々はこれまで視覚誘導性の自己運動錯覚 について生理学的影響を検証してきた ${ }^{4 \sim 6)}$ 。この手 法では，現実の四肢と空間的に一致した位置に身体 運動の動画を提示することにより, 視覚入力単独で 運動錯覚を誘導することができる，そこで，本研究 では単独でも運動錯覚を誘導できるような振動刺激 と視覚刺激を同時に付与した際に生じる運動感覚の 変化について検証した。

\section{2 方法}

\section{(1) 対象}

対象は健康な右利きの成人 7 名 $(24.6 \pm 3.7$ 歳, $166.7 \pm 5.5 \mathrm{~cm}, 62.6 \pm 6.8 \mathrm{~kg})$ とした。本研究は 札幌医科大学倫理委員会の承諾を得た上で実施した また, ヘルシンキ宣言に従い, 被験者のプライバシ 一と人権の保護に十分留意をして実験を実施した. 測定肢位は，安楽な椅子座位とした。両側の手関節 は掌背屈中間位で自作の台に第 5 中手骨が接地する ようリラックスした状態で前腕を置いた。

(2) 振動刺激

刺激端子は，右手関節背屈筋を刺激するよう前腕 遠位部の背側に固定した (図 $5 \mathrm{~B}$ )。振動刺激の周 波数は $40 \mathrm{~Hz}, 60 \mathrm{~Hz}, 80 \mathrm{~Hz}$ とした。刺激時間は, 全ての条件で 3 秒間とした。詳細な設定は 2.2 項

(2)に記載した.

(3) 視覚刺激

視覚刺激として，事前に撮影した手関節掌屈運動 の動画を用いた。動画の撮影にはWebカメラ (Webcam C920t, Logicool HD Pro, Switzerland) を用いた。 カメラの位置は測定肢位をとった被験者 の右手の直上とし, カメラのレンズ面は机に対して

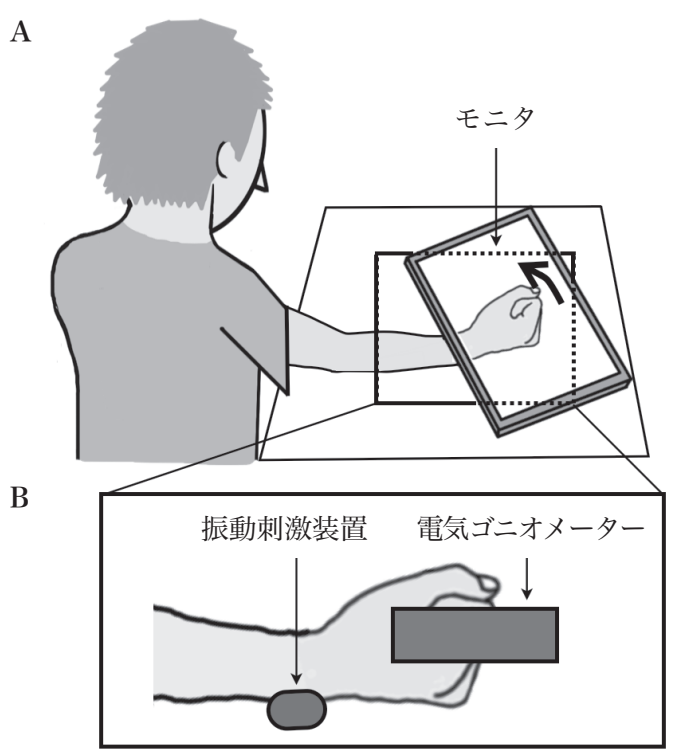

図 5 実験環境

実験環境を示した模式図である。動画を提示するモ二夕は右 手の上に設置した。刺激端子は，右手関節背屈筋を刺激する よう，前腕遠位部の背側に固定した.

平行になるように調節した。撮影する運動は，右手 関節背屈筋に $60 \mathrm{~Hz}$ で振動刺激を行った際に知覚 した運動を同側で再現させた際の手関節掌屈運動と した。つまり，動画を観察することによって錯覚す る運動は, $40 \mathrm{~Hz}$ で振動刺激した場合に錯覚する運 動よりも速く, $80 \mathrm{~Hz}$ で振動刺激した場合よりも遅 くなる. 撮影した動画は, 被験者の右前腕から手部 の上に設置したモニ夕に提示した。 その際, 動画の 前腕とモニ夕の下に置いた実際の前腕の連続性が保 たれるよう，モ二夕の位置を調整した（図 $5 \mathrm{~A}$ ).

以上の環境下において，事前に自己運動錯覚が十分 に誘導されるようになるまで動画を観察させた。自 己運動錯覚の強度は, 5 分毎に 7 リッカートスケー ルを用いて確認した。「私は自分の手が実際に動い ているように感じました」という質問に対し，7リ ッカートスケールが+1(やや同意する) 以上になっ た時点で, 自己運動錯覚が十分に誘導されたと判断 した。

\section{(4) 実験条件}

実験条件として，3 段階の周波数での振動刺激中 に動画を提示する条件（Vib+Vis 条件）と黒画面 
84 バイオメカニズム 23

を提示する条件（Vib 条件）の合計 6 条件を設定し た，振動刺激の開始と動画の屈曲運動が開始する夕 イミングを一致させるため, 振動刺激と動画開始の タイミングは自作のプログラム（LabVIEW, National Instruments, USA）にて制御した。各条 件は 5 試技ずつ実施した。なお，試技間には十分な 休憩を挟んだ。

振動刺激中に知覚した関節運動を非刺激側で再現 させ，電気ゴニオメーターで再現中の手関節角度を 記録した。そして, 得られたデータから角速度を算 出した。角速度の算出方法は，2.2 項（5）に記載 した.

(5) 統計学的解析

角速度のデータについて Levene の等分散性検定 を行った、その結果，等分散が仮定されたため，振 動刺激周波数と視覚刺激の有無を要因とした二元配 置分散分析を実施した，有意な交互作用があった場 合，多重比較として単純主効果の検定を行った，有 意水準は $5 \%$ とした。

\section{3 結果}

動画を提示した場合の運動錯覚の強度は，全ての 被験者において7リッカートスケールで+1 以上で あり，黒画面を提示した場合はー3であった。また， 背屈筋への振動刺激により全ての被験者で手関節掌 屈運動の運動錯覚が誘導された。以上より，本研究 で用いた視覚刺激と振動刺激はどちらも単独で運動 錯覚を誘導できるような刺激であったといえる。

本研究では Vib+Vis 条件に打いて $40 \mathrm{~Hz}$ の周波 数で振動刺激を与えた場合に知覚する運動の角速度 が，Vib 条件において $40 \mathrm{~Hz}$ で刺激した場合に知覚 する運動の角速度よりも増大した（図 6)。これに 対し， $60 \mathrm{~Hz}$ と $80 \mathrm{~Hz}$ で振動刺激を与えた場合には, $\mathrm{Vib}$ 条件と Vib+Vis 条件で知覚する運動の角速度 に差はなかった。

二元配置分散分析の結果, 振動刺激周波数の要因 に有意な主効果があり（ $\mathrm{F}=12.708, \mathrm{p}=0.008)$ ， 振動刺激周波数と視覚刺激の要因には有意な交互作 用があった（ $\mathrm{F}=4.178, \mathrm{p}=0.042)$.

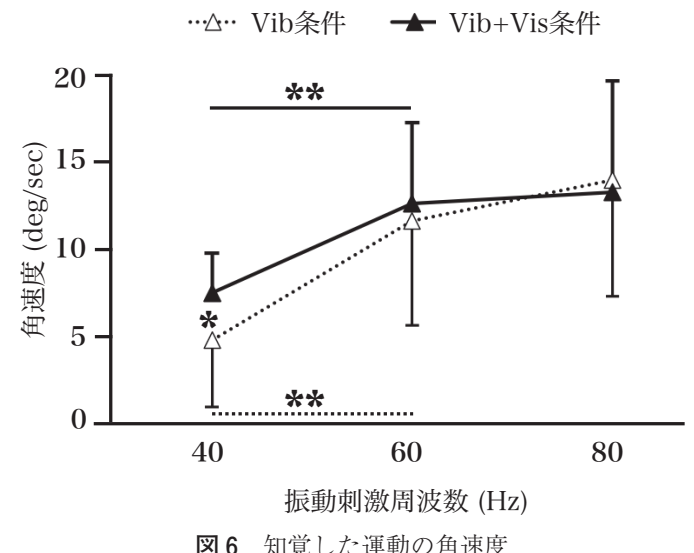

知覚した運動を再現させた際の角速度の平均値士標準偏差を 示す. $(*: p<0.05, * *: p<0.01)$

\section{4 考察}

振動刺激の周波数と Ia 群線維の発射頻度は 1 対 1 の関係にあり, Ia 群線維の発射頻度の増加に伴い, 知覚する運動の角速度が増大する ${ }^{9)}$. 本研究では, 周波数に依存して知覚する運動の角速度が増大した ことから，振動刺激によって知覚する運動錯覚の強 度は適切に段階付けられていたといえる。また， 7 リッカートスケールの結果から Vib+Vis 条件では 動画を用いた視覚刺激によって運動錯覚を誘導する ことができており, Vib 条件では全ての被験者で運 動錯覚が誘導されなかったことが示された。

本研究では, 振動刺激単独よりも視覚刺激単独で 知覚する運動のほうが速い条件において, それらの 刺激を組み合わせることにより，それぞれ単独で刺 激した場合に知覚する運動とは異なる速度の運動を 知覚した。これは, 深部感覚と視覚に対して運動錯 覚を誘導するような感覚刺激を同時に付与した場合， それら単独の刺激で生じる運動感覚情報が統合され 結果として知覚する運動感覚が変化する可能性を示 すものであると考える.

Hagura らは, ヘッドマウントディスプレイ内に 自身の手の静止画を映し出し，その映像を観察させ た状態で振動刺激を与えた。その結果，閉眼の状態 で振動刺激を行なった場合と比較して，静止画を観 察しながら振動刺激を与えた場合には運動錯覚が生 
じにくくなった ${ }^{21)}$. さらに，ディスプレイに提示す る映像が，振動刺激を与えている側の手であるか, それとも非刺激側の手であるかによっても，振動刺 激によって誘導される運動錯覚の強度が異なること が明らかになった。これは，視覚を介して刺激側の 手関節が動いていないという情報が得られたことで, 筋紡錘からの求心性入力によって誘導された運動錯 覚が弱まったということを示している。

これに対して, 本研究では視覚刺激によって運動 錯覚が誘導されていたことから，視覚を介して刺激 側の手関節が動いているという運動感覚情報が生じ ている。そのような状況下においても, 運動感覚が 変化する背景には, それぞれの感覚入力によって生 じる運動感覚情報が統合されるようなメカニズムが 存在することが示された。しかし, 本研究では振動 刺激単独よりも視覚刺激単独で知覚する運動が遅い 場合には，それらの刺激を組み合わせて実施しても， 振動刺激単独の場合と比較して知覚する運動の速度 は変化しなかった。このことから, 深部感覚と視覚 のような異種感覚入力の統合によって運動感覚が生 成される場合には, それぞれの感覚入力量によって 運動感覚へ優位に寄与する感覚が異なる可能性が示 唆された。

\section{4. まとめ}

本稿では, 随意的な運動のイメージと感覚入力の 統合, および, 深部感覚と視覚といった異種感覚入 力の統合という視点から, 運動感覚の生成機構を明 らかにするために行なった研究結果について述べた。 運動感覚が生成され, 運動を知覚する過程において は, さまざまな感覚受容器から生じる感覚入力の統 合，およびそれらの感覚種を介して生じる運動感覚 と運動を実行しようとする際に発せられる運動指令 が統合されるような機構が存在する。本研究により, 拮抗関係にある筋からの感覚入力が統合され運動を 知覚する場合においても, 感覚入力と運動イメージ による脳活動が統合されること，および自己運動錯 覚を誘導できるような異種感覚入力が統合され，運 動感覚が生成されることが明らかとなった。

\section{謝辞}

本研究は, 笹川科学研究助成, 科学研究費若手研 究 B (26750191)，科学研究費基盤研究 B(26282157) の助成を受けたものである.

\section{参考文献}

1）金子文成：脳卒中片麻瘏患者における体性感覚障害が運 動機能に及ぼす影響，PT ジャーナル，48(9)，809-816， (2014).

2）金子文成：感覚障害に対する理学療法, 市橋則明（編）: 運動療法学 障害別アプローチの理論と実際第 2 版, 292-307, 文光堂, (2014).

3) Von Holst, E.: Relations between the central nervous system and the peripheral organs, Br J Anim Behav, 11 (2), 89-94, (1954).

4) Kaneko, F., Yasojima, T. and Kizuka, T.: Kinesthetic illusory feeling induced by a finger movement movie effects on corticomotor excitability, Neuroscience, 149 (4), 976-984, (2007).

5) Aoyama, T., Kaneko, F., Hayami, T. and Shibata, E.: The effects of kinesthetic illusory sensation induced by a visual stimulus on the corticomotor excitability of the leg muscles, Neurosci Lett, 514(1), 106-109, (2012).

6) Kaneko, F., Blanchard, C., Lebar, N., Nazarian, B., Kavounoudias, A. and Romaiguère, P.: Brain regions associated to a kinesthetic illusion evoked by watching a video of one's own moving hand, PLoS One, 10(8), e0131970, (2015).

7) Shibata, E., and Kaneko, F.: Differences between afferent inputs from antagonistic muscles affect kinesthetic perception during motor imagery, 17th International WCPT Congress, Proceeding, 57, (2015)

8) Goodwin, GM., McCloskey, DI. and Matthews, PB.: The contribution of muscle afferents to kinaesthesia shown by vibration induced illusions of movement and by the effects of paralysing joint afferents, Brain, 95(4), 705748, (1972).

9) Roll, JP. and Vedel, JP.: Kinaesthetic role of muscle afferents in man, studied by tendon vibration and microneurography, Exp Brain Res, 47(2), 177-190, (1982).

10) Roll, JP., Vedel, JP. and Ribot, E.: Alteration of proprioceptive messages induced by tendon vibration in man: a microneurographic study, Exp Brain Res, 76(1), 213222, (1989).

11) Burke, D., Hagbarth, KE., Löfstedt, L. and Wallin, BG.: The responses of human muscle spindle endings to vibration of non-contracting muscles, J Physiol, 261(3), 673-693, (1976).

12) Gilhodes, JC., Roll, JP. And Tardy-Gervet, MF.: Perceptual and motor effects of agonist-antagonist muscle vibration in man, Exp Brain Res, 61(2), 395-402, (1986).

13) Kitada, R., Naito, E. and Matsumura, M.: Perceptual changes in illusory wrist flexion angles resulting from motor imagery of the same wrist movements, Neurosci- 
ence, 109 (4), 701-707, (2002).

14) Calvin-Figuière, S., Romaiguère, P., Gilhodes, JC. and Roll, JP.: Antagonist motor responses correlate with kinesthetic illusions induced by tendon vibration, Exp Brain Res, 124(3), 342-350, (1999).

15) Naito, E., Kochiyama, T., Kitada, R., Nakamura, S., Matsumura, M., Yonekura, Y. and Sadato, N.: Internally simulated movement sensations during motor imagery activate cortical motor areas and the cerebellum, $J$ Neurosci. 22 (9), 3683-3691, (2002).

16) Collins, DF. and Prochazka, A.: Movement illusions evoked by ensemble cutaneous input from the dorsum of the human hand, J Physiol, 496 (3), 857-871, (1996).

17) Collins, DF., Refshauge, KM., Todd, G. and Gandevia, SC.: Cutaneous receptors contribute to kinesthesia at the index finger, elbow, and knee, J Neurophysiol, 94(3).
1699-1706, (2005)

18) Ramachandran, VS., Rogers-Ramachandran, D. and Cobb, S.: Touching the phantom limb, Nature, 377 (6549), 489-490, (1995)

19) Kavounoudias, A., Roll, JP., Anton, JL., Nazarian, B., Roth, M. and Roll, R.: Proprio-tactile integration for kinesthetic perception: an fMRI study, Neuropsychologia, 46 (2), 567-575, (2008).

20) Blanchard, C., Roll, R., Roll, JP. and Kavounoudias, A.: Combined contribution of tactile and proprioceptive feedback to hand movement perception, Brain Res, 1382, 219-229, (2011).

21) Hagura, N., Takei, T., Hirose, S., Aramaki, Y., Matsumura, M., Sadato, N. and Naito, E.: Activity in the posterior parietal cortex mediates visual dominance over kinesthesia, J Neurosci, 27 (26), 7047-7053, (2007).

\title{
The psychophysical study of kinesthesia based on perceptual integration
}

\author{
Eriko SHIBATA $^{1,2}$, Fuminari KANEKO ${ }^{1,2}$, Ryosuke TAKAHASHI ${ }^{1,3}$
}

\author{
${ }^{1}$ Development Research Group for Advanced Neuroscience-based Rehabilitation, Sapporo Medical \\ University \\ ${ }^{2}$ First Division of PhysicalTherapy, Sapporo Medical University \\ ${ }^{3}$ Asahikawa Rehabilitation Hospital
}

\begin{abstract}
Kinesthesia is the sense that enables awareness of bodily position, weight, or movement. The perceptual integration of afferent inputs from sensory receptors i.e., muscle spindle or cutaneous, and the efferent inputs from the central nervous system that trigger intentional movement contribute to the generation of kinesthesia. We investigated the mechanism of kinesthesia using the psychophysical index. This paper describes two psychophysical studies : 1) the effect of afferent inputs from muscle spindle on kinesthetic perception during motor imagery, and 2) kinesthetic illusion induced by perceptual integration of proprioception and vision. The results of these studies demonstrate that perceptual integration contributes to kinesthetic perception when the latter is induced by afferent inputs from two antagonistic muscle spindles during motor imagery, or by differing sensory inputs, such as proprioception and vision.
\end{abstract}

Key Words : Kinethesia, Muscle spindle, Motor imagery, Vision 